\title{
Lean and Green Synergies in Supply Chain Management
}

\author{
Lucila M. S. Campos and Diego A. Vazquez-Brust
}

\section{Structured Abstract}

\section{Purpose}

The purpose of this paper is to investigate how synergies between lean and green supply chain practices emerge. In particular, we explore which practices identified in the literature are actually implemented in a synergic way and we determine what synergic results they bring.

\section{Design/methodology/approach}

An in-depth case study of the Brazilian subsidiary of a large multinational company was conducted using interviews, in-plant observations, and document analysis.

\section{Findings}

The majority of the practices (26 out of 31 ) bring synergic results to lean and green performance. Synergies can emerge spontaneously (rather than being strategized) even when the implementation of green and lean practices is compartmentalised in different areas, with no department or supportive management team to treat them in a joined way. The strongest synergic results are found in practices related to suppliers and customers because these supply chain actors act as bridges between the lean and green areas.

\section{Research limitations/implications}

We did not have access to the company customers and suppliers. This restriction made our analysis of drivers skewed towards the perspective of the focal company and the way they framed their interactions. Secondly, our assessment of synergies was in the majority of cases qualitative.

\section{Originality/value}

Empirically, it is the first time that all synergic practices identified in the literature are explored through a case study. Theoretically, we developed a model of determinants of lean and green synergies based on constructs emerging from our data; behavioural literature in synergies, and research on synergies in mergers \& acquisitions.

Key words: Lean production, Green supply chain, SCM practices, Domestic Appliance Industry, Brazil.

\section{Introduction}

The integration of environmental issues with lean manufacturing and supply chains is still a major challenge for management research (Piercy and Rich, 2015). Studies exploring the links between environmental management and lean production sprang back to Florida's (1996) article, "Lean and Green: The move to environmentally conscious manufacturing", which argued that synergies between lean manufacturing practices and environmental protection practices resulted in better economic and environmental performance when the practices were jointly implemented by a company. In turn, synergies between operational and environmental practices were proposed by Russo and Fouts (1997) as a main mechanism leading to a positive relation between environmental and economic performance. Lean operations reduce costs as they aim to use fewer resources and to generate less waste per unit of production than manufacturing by traditional means (Forrester et al 1 , 2010). The benefits 
are clear in terms of environmental performance: less use of materials and water consumption and fewer emissions are results that can be expected from reduced energy consumption (Corbett and Klassen, 2006). However, despite the auspicious start of Florida's (1996) and Russo and Fouts' (1997) pioneering works, Azevedo et al. (2012) found little evidence of rigorous academic research in the synergies between lean and green. Many articles have theorised synergies between a variety of manufacturing practices and environmental practices. However, other researchers have counter argued not only that empirical support for the existence of alleged synergies is elusive but also that lean and green advocates underestimate the importance of trade-offs between lean and green practices. Such trade-offs are likely to result in diminished environmental performance if companies are forced to choose between productivity and greenness (Garza-Reyes, 2015). Indeed, as Sobral et al. (2013) points out, there is a surprising paucity of empirical evidence regarding how the relationship between lean and green happens in a factory's operational level and how the people who work directly or indirectly on lean and green operations understand potential synergies and trade-offs. In particular, there is relative scarcity of empirical studies on lean and green from a supply chain perspective (e.g. Carvalho et al., 2010; Dües et al., 2013; Wiengarten et al., 2013), especially those that consider not only the people who work in the focal company, but also the suppliers and customers. As a consequence, there are still many gaps in our understanding of lean and green synergies. What makes the synergy happen in a company that uses lean and green practices? Do synergies spontaneously emerge when companies implement lean and green practices separately in a factory or do synergies need to be planned and nurtured to develop? What is the role - if any - of suppliers and customers in the enablement of synergies?

The paper aims to provide answers to such questions by exploring the synergy between lean and green supply chain practices through an in-depth case study. The case study was conducted in a Brazilian subsidiary of a large multinational company; this company has already implemented 31 practices theorised as integrated lean and green by the literature. In particular, we investigate which of these practices are really implemented in a synergic way and we explore which synergic results they bring. Our results suggest that the majority of the practices (26 out of 31 ) bring synergic results to lean and green performance, even when the managers implementing such practices do not fully understand, or simply dismiss, potential synergies between those lean and green practices. Synergies can emerge spontaneously (rather than being strategized) even when the implementation of green and lean practices is compartmentalised in different areas, with no department or supportive management team to treat them in a joined way. Our results also show that the strongest synergic results are found in practices related to suppliers and customers. Suppliers and customers act as middle men and enable the emergence of synergies as both "lean" and "green" managers interact with them. In other words, supply chain actors provide channels for knowledge transfer and for the development of complementarities between business functions that may otherwise work in organizational silos. Our paper helps to bridge a gap in the literature, where the process of synergies' formation and implementation and the engagement of green with lean operations remain under examined (Piercy and Rich, 2015). The results also bring attention to a practice not previously identified in the literature: hybrid sourcing. Hybrid sourcing refers to a mode of supply where the production line of long-term suppliers is hosted inside the focal firm's factory and uses their physical and administrative resources. We observed significant synergies arising from hybrid sourcing.

The paper is organized as follows. First we reviewed the relevant literature on lean and green paradigms and practices and what we define as synergy. Next, we present the methodology used to develop this study. This is followed by results from the case study and discussion, presenting a model of Lean and Green Synergies. Finally, the main conclusions are drawn. 


\section{Literature Review}

\subsection{Lean and Green Synergy: Definitions and Conditions}

The word synergy has its roots in the Greek term 'synergos': working together. Goold and Campbell (1998, p.133) define synergy as "the ability of two or more units or companies to generate greater value working together than they could working apart". Accordingly, we define lean and green synergy as the additional effects produced by the implementation of green practices and lean practices together. Simply stated, lean and green synergy results when the value added to environmental and financial performance by the whole (lean and green) is greater than the sum of the value added by the individual parts (lean or green, separately). Martinez et al. (2012) point out that lean and green synergy is achieved when there is a catalytic association with mutual lean and green benefits: the implementation of lean practices triggers better environmental performance and vice versa. Such catalytic process occurs when there is recombination of knowledge resources, helping to realize intraorganizational knowledge synergies (Carnabucci and Operti, 2013).

As the literature on synergies in mergers and acquisitions has shown, the extent to which the combination of two distinct sets of knowledge resources delivers synergies depends upon the extent to which these knowledge resources complement and relate to each other (Gupta and Roos, 2010). Observe first that the greater the complementarity between the knowledge resources of the firm, the greater the value of innovation from the recombination of this internal knowledge (Makri et al., 2010). Second, greater relatedness between internal knowledge resources will lower coordination and communication costs between different units within the firm, enabling them to work together more easily (Karim and Kaul, 2015). The quality of knowledge developed by a field is another determinant of synergies. Quality of knowledge resources strengthens the potential for intra-organizational knowledge recombination. Recombination of strong knowledge resources is likely to result in more valuable innovations (Kogut and Zander, 1992). Therefore, the cognitive preconditions for lean and green synergies to develop are that, a) "lean" knowledge and "green" knowledge fields must be both of high quality, and b) "lean and green" knowledge fields must be closely related and complementary. When such preconditions are fulfilled, there is high potential for synergies to develop.

However, to what extent synergies are realized will depend on whether integration between lean and green is enabled or hampered by the characteristics of the relations between the organizational actors involved in the recombination of knowledge (Larsson and Finkelstein, 1999). The application of relational exchange theory in a supply chain context has revealed that synergies are realized when actors do not resist the exchange of information and resources, engage in joint learning processes, and are willing to share both benefits and costs of discovery and exploitation of new opportunities (Simatupang et al., 2004; Hoejmose et al., 2012). Power and trust are two relational factors pointed out by researchers as major determinants of the type of relationship leading to fulfilment of synergy potential (Dabhilkar et al., 2016; Wu et al., 2004; Handfield and Bechtel, 2004; Giamakis et al., 2004; Lasker et al., 2001; Hardy et al., 1998).

Trust is the feeling of predictability that the other part in a transaction will not involve in opportunistic behaviour. Trust relies on reciprocal communication and shared meaning (Hardy et al., 1998). Trust favours the realization of synergies because it increases relationship commitment and willingness to invest in a relationship (Wu et al., 2004); it also reduces perceptions of risks attached to sharing knowledge (Capaldo and Giannocaro, 2015) and underlies successful integration of organizational resources between different functional areas (Larsson and Finkelstein, 1999). Trust between supply chain actors is a powerful predictor of positive performance outcomes in supply chain contexts (Capaldo and Giannocaro, 2015; Lee et al., 2010), and, in particular, the success of lean practices (Giamakis 
and Croom, 2004) and Green Supply Chain Management (Hoejmose et al., 2012). The highest levels of synergy occur when trust emerges spontaneously through reciprocal communication and shared meaning, although synergies also arise when trust is created through repeated relationships and equal participation (Hardy et al., 1998).

Power is the ability of one group or individual to get another group or individual to do something. Research on the impact of power in collaboration, partnerships, and synergies offers mixed views. On the one side, power is needed to enforce compliance with the terms agreed upon in a contract and to reduce opportunism (Wu et al., 2004). The appropriate use of power can enhance supply chain relationships' commitment and performance (Zhao et al., 2008). However, when power asymmetries between parts in a transaction are significant, this power differential creates opportunities for the most powerful actor to behave opportunistically, coercing the weakest actor or simply excluding it from dialogue and decision-making (Dabhilkar et al., 2016; Lasker et al., 2001; Hardy et al., 1998). Power asymmetries undermine collaboration and stifle innovation in supply chains because they act as a deterrent to knowledge sharing and risk taking (Handfield and Bechtal, 2004; Dabhilkar et al., 2016) thus hampering integration and commitment between partners (Wu et al., 2004). Power differentials have the potential to seriously undermine synergies and prevent recombination of knowledge (Lasker et al., 2001). Synergy is very low or non-existent when there is a dominant actor that uses its power to reduce risk, co-opt decision-making, increase predictability and maintain status-quo; furthermore, synergies are significantly reduced when there is a power imbalance and one of the partners is dependent on the other, even if the dominant part does not exercise coercion (Hardy et al., 1998).

\subsection{Lean and Green Practices and Synergy}

The analysis of state-of-the-art "green" and "lean" literatures suggests that both cognitive field preconditions have been fulfilled by extant research. Although studies of lean and green together are scarce, in a separate way both fields of knowledge, lean and green, can be considered deeply explored by academics and in companies (see Shah and Ward, 2003, 2007; Anand and Kodali, 2008, 2010; Gurumurthy and Kodali, 2009; González-Benito, 2008; Arantes et al., 2014, Azevedo et al., 2011). If we accept that abundance of research is a proxy for quality of knowledge, this equation indicates that both fields have developed high knowledge quality.

Lean and Green knowledge fields also exhibit complementarities. The main objective of Lean is to locate and eliminate waste, waste being broadly defined as any activity in a process that does not add value for customers (Shah and Ward, 2007). Minimization of waste and reduced use of natural resources is a major objective of Environmental Management, which is closely related with Lean's waste elimination objective. The degree of relatedness is even higher in terms of knowledge generated by Lean literature and Green Supply Chain literature. Green Supply Chain Management practices are all those actions carried on within the supply chain to eliminate or reduce any negative environmental impact without sacrificing quality, productivity, and operating costs (Azevedo et al., 2011). Similarly, lean production has a supply chain scope; some practices are related to suppliers (supplier feedback, just-intime delivery by suppliers, supplier development), some are related to operations (pull system, set-up, flow, employee involvement), and some related to customers' relationships (risk sharing, co-design with customers) (Anand and Kodali, 2008).

Despite the potential for synergies to develop that draw from existing knowledge, there is paucity of literature conceptualizing lean and green in a synergic way. When lean and green have been analysed together, the approach was quantitative and did not delve into the relationship between lean and green practices or the conditions under which these interactions yield maximum synergies (Galeazzo et al., 2014). Even more scarce are theoretical and 
empirical studies analysing synergies between lean and green practices in the supply chain. Table 1 shows the main integrated lean and green supply chain practices described in the literature ${ }^{1}$. We identified 21 papers, which addressed lean and green practices in a supply chain perspective. These are classified following Shah and Ward (2007) into: Practices involving the focal company and its suppliers (Sn), practices involving the focal company production operations (On), and practices involving the focal company and its customers (Cn).

After studying the papers from Table 1, we realized that except for the work conducted by Dües et al. (2013), the papers discuss synergic practices without defining what they understand by synergy. This ambiguity undermines their theoretical and policy contributions. Conceptually, there is little analysis of the extent of integration of lean and green practices and the conditions required to develop synergies. In the majority of papers, cognitive and behavioural factors influencing synergy potential (quality of knowledge, relatedness, trust, power) are omitted, understudied, or weakly conceptualized. Empirical studies are vague in terms of the criteria applied to verify the existence of synergies. Existing studies remain unclear on the issue of to what extent additional value is created when practices were implemented together, or to what extent alleged synergies are not just parallel implementation of practices with no added value. Therefore, one of the intentions of this work was to understand in which situations lean and green practices actually bring synergies resulting into something greater or better than the sum of lean and green. From Table 1, we prepared a structured script of questions that were answered in some way during the case study, either through semi-structured interviews or through visual observations and/or analysis of documents. The next topic will explain in more detail the methodology adopted.

\section{Methodology}

In order to achieve the main objective, to better understand when and how the synergy happens, an in-depth case study approach was adopted. The focus was on a real and contemporary organizational issue: which of the main theoretical lean and green practices are really implemented and synergic in a company that uses lean and green practices? Do synergies spontaneously emerge when the company implements lean and green practices separately in a factory or do synergies need to be planned and nurtured to develop? What is the role of suppliers and customers in the enablement of synergies - if any?

\footnotetext{
${ }^{1}$ The search of articles drew from EBSCO, ISI Web of Science, and Scopus databases. The search comprised papers from 1990 to 2015, including articles 'in-press' that would be later published in 2016. Search strings included the words "lean and green" (for title, keywords, abstract and/or text). After deleting duplicated papers, we obtained 178 papers. Next, we read all the abstracts and selected 26 papers related specifically to lean and green practices. After analysing all of them, five were not considered due to at least one of these reasons: i) they presented only one practice, or ii) their authors were previously represented in other studies and offered a similar approach).
} 
Table 1: Lean and green practices from literature review

\begin{tabular}{|c|c|c|c|c|c|c|c|c|c|c|c|c|c|c|c|c|c|c|c|c|c|c|}
\hline Cat. & INTEGRATED LEAN AND GREEN PRACTICES & 1 & 2 & 3 & 4 & 5 & 6 & 7 & 8 & 9 & 10 & 11 & 12 & 13 & 14 & 15 & 16 & 17 & 18 & 19 & 20 & 21 \\
\hline S1 & Supplier network/collaboration/training (long-term relationship) & * & $*$ & & & * & & * & * & & * & & * & $*$ & * & & & & $*$ & & * & * \\
\hline S2 & Supplier evaluation/certification/auditing (environm. requirements) & & $*$ & & & * & & * & & * & * & & & * & & & & & * & * & & * \\
\hline S3 & Use of green/less packages (from suppliers) & & & & & & & & & & & $*$ & * & * & & * & & & * & & & \\
\hline S4 & Geographic concentration & & & & & & & & & & & & & * & & & & & $*$ & & & \\
\hline S5 & Environmental risk sharing with suppliers & & & & & * & & * & & & * & & * & & & & & & $*$ & & & \\
\hline S6 & Reducing number of suppliers & & & & & & & & & & & $*$ & & & & & & & $*$ & & & \\
\hline S7 & JIT delivery & & $*$ & & & & & * & & & * & & * & & * & $*$ & & & * & & & * \\
\hline O1 & Employees involvement, training and empowerment & * & $*$ & $*$ & & $*$ & $*$ & * & & * & * & & & & * & & & & & & * & \\
\hline $\mathrm{O} 2$ & Continuous improvement/Kaizen & * & $*$ & * & & $*$ & $*$ & & * & * & & $*$ & & & * & & * & & & & & \\
\hline $\mathrm{O} 3$ & Inventory reduction & * & $*$ & * & $*$ & & & * & & & & $*$ & * & & * & & & & & & & \\
\hline $\mathrm{O} 4$ & Information shared through the chain or Information system & & * & * & & * & * & * & & & * & & & * & & & & & * & & * & \\
\hline $\mathrm{O} 5$ & $5 \mathrm{~S}$ & * & $*$ & & & & & & * & & & $*$ & & & & & * & & & & & \\
\hline O6 & Total Productive/Preventive Maintenance (TPM) & * & * & & & & & & * & & & & & & & & * & & & & & \\
\hline $\mathrm{O} 7$ & Six sigma & & & & & & & & * & & & & & & & & $*$ & & & & & $*$ \\
\hline O8 & 3Rs (Reduce, Reuse and Recycle) & & * & & & & & * & * & & & & * & * & * & & & * & & * & & \\
\hline O9 & $\mathrm{TQM}^{1}$ and/or TQEM ${ }^{2}$ & & & & & & & & * & & * & & & & * & * & & & & * & & * \\
\hline $\mathrm{O} 10$ & Kanban & & $*$ & & & & & & & & & $*$ & & & & & $*$ & & & & & \\
\hline $\mathrm{O} 11$ & Waste reduction & & & * & $*$ & * & * & * & * & * & * & $*$ & * & & * & * & & * & & * & * & * \\
\hline $\mathrm{O} 12$ & Pollution prevention & & & * & $*$ & * & & & * & & * & & & & $*$ & & & * & & * & & \\
\hline $\mathrm{O} 13$ & ISO systems certifications (or other systems) & & $*$ & & $*$ & & & $*$ & * & $*$ & * & & & & $*$ & $*$ & & * & & * & & * \\
\hline $\mathrm{O} 14$ & Lead time and/or set-up reduction and/or total time reduction ${ }^{3}$ & & & & & & & * & & & & $*$ & * & * & & & & * & & * & & * \\
\hline $\mathrm{O} 15$ & Emissions reduction & & & * & $*$ & & & & & & * & & * & & * & & & & & & & \\
\hline $\mathrm{O} 16$ & Reduction of hazardous/materials/resources consumption ${ }^{4}$ & & & * & & & & * & & & * & & * & & * & * & & & & & & * \\
\hline $\mathrm{O} 17$ & Use of green technology & & * & * & & & & & & & & & * & & * & & & & & & & \\
\hline $\mathrm{O} 18$ & Value stream map/focus or sustainable VSM & & & & & & & * & & & & $*$ & & & & & * & & & & & \\
\hline O19 & JIT philosophy & & $*$ & & & & & * & & & * & & * & & & * & * & * & & * & & * \\
\hline $\mathrm{C} 1$ & Customer relationship/interaction & & & & & * & & * & & & * & & * & $*$ & * & & & & & & & * \\
\hline $\mathrm{C} 2$ & Reverse logistics & & & & & & & & & & * & & * & * & & & & & & & & $*$ \\
\hline $\mathrm{C} 3$ & Environmental risk sharing with costumers & & & & & * & & * & & & * & & & * & & & & & & & & \\
\hline $\mathrm{C} 4$ & Environmental products and/or eco-design & & & & & & & * & & & * & & * & & * & & & & & & & \\
\hline $\mathrm{C} 5$ & Use of green/less packages (to costumers) & & & & & & & * & & & * & $*$ & * & * & & * & & & & & & * \\
\hline
\end{tabular}

${ }^{1}$ Total Quality Management; ${ }^{2}$ Total Quality Environmental Management; ${ }^{3}$ Within operations and transportation; ${ }^{4}$ Meaning efficient uses of materials and resources as water, energy, etc.

References: 1-Sobral et al. (2013); 2-Jabbour et al. (2013b); 3-Rothenberg et al. (2001); 4-King and Lenox (2001); 5-Simpson and Power (2005); 6-Maxwell et al. (1998); 7Dües et al. (2013); 8-Vais et al. (2006); 9-Pojasek (2008); 10-Corbett and Klassen (2006); 11-Miller et al. (2010); 12-Carvalho et al. (2011); 13-Espadinha-Cruz et al. (2011); 14-Florida (1996); 15-Govindan et al. (2015); 16-Parveen et al. (2011); 17-Wiengarten et al. (2013); 18-Azevedo et al. (2012); 19-Hajmohammad et al. (2013); 20-Duarte and Cruz-Machado (2015); 21-Carvalho et al. (2010). 
The case study was a Brazilian big focal company from the appliance sector. We chose Brazil because the country's importance in global supply chains is growing, and its government had been consistently promoting lean practice and green practices and research (Jabbour et al., 2013b). We chose the appliance sector because it is one of the most important sectors in the Brazilian industrial setting and around the world as well. It is an oligopolistic market and one of the industries that has faced significant changes in recent decades (Calife et al., 2010). We also evaluated the sector as offering high potential to identify cases of lean and green, since the field knowledge preconditions we identified in the previous section are likely to be satisfied by the literature exploring the sector. The appliance sector is part of the electroelectronics sector, which is one of the sectors most studied in the field of Green Supply Chain Management (Jabbour et al., 2013a), and it is also a sector widely studied in lean research. The case study comprised 4 one-day visits to the factory and follow-up Skype meetings with managers over a period of 10 months. Data triangulation was adopted, based on interviews, in-plant observations, and document analysis (Yin, 1994). During the visits we observed operations, conducted formal interviews with managers, specialists and trainees, interacted with employees in the canteen, and informally interviewed line workers regarding floor level engagement with lean and green. Researchers were given access to the site's confidential internal reports including environmental auditing, environmental management systems, and value stream maps. In addition, we downloaded the Global GRI reports, Global Sustainability Report, Integrated Systems for Environmental Health and Safety and Quality, Integrated Environmental Health and Safety (EH\&S) for suppliers and Total Quality Management (TQM).

Table 2: Personnel Interviewed

\begin{tabular}{|c|c|c|}
\hline Interviewed & Job title & Date (Duration) \\
\hline Interviewed $1[$ [I1] & Sustainability Specialist & January 2015 (115 minutes) \\
\hline Interviewed $2[$ [I2] & Product Development Specialist & April 2015 (46 minutes) \\
\hline Interviewed $3[\mathrm{I} 3]$ & Lean Manager & March 2015 (57 minutes) \\
\hline Interviewed 4 [I4] & Quality Manager & $\begin{array}{c}\text { January } 2015 \text { (60 minutes) } \\
\text { June } 2015 \text { (30 minutes) } \\
\text { August } 2015 \text { (32 minutes) }\end{array}$ \\
\hline Interviewed 5 [I5] & Lean Trainee & March 2015 (18 minutes) \\
\hline Interviewed $6[16]$ & Quality Trainee & March 2015 (21 minutes) \\
\hline
\end{tabular}

An interview guide with open-ended questions was prepared based on the literature review and practices identified in Table 1. As the interviews and the analysis progressed, questions were directed toward emergent themes and concepts. All interviews were recorded and transcribed. Interpretative codes procedures were applied. The first codification was used to acquire an understanding of the interviewees' perceptions regarding the implementation of integrated lean and green practices at the company and a preliminary assessment of synergy's drivers and obstacles. A second codification, combined with analysis of secondary data and observation in-situ, was used in order to acquire evidence of whether the integrated lean and green practices were synergic. The second codification included interpretive analysis to identify second order constructs linking the drivers and obstacles identified in the first stage, resulting in an empirically derived lean and green synergy model.

\section{Results}

Tables 3-9 summarise our results, which are organised with the following structure: a) the level of this practice (if it was totally implemented (TI) or partially implemented (PI)); b) the categories (codes) related to Table 1; c) and d) information on whether the practice helps 
lean management (LM) and/or environmental management (EM) respectively; e) if it is synergic (yes, no, or partially synergic); f) the results of synergy; and finally g) group of quotations that supports the findings and/or practices.

We observe that both lean management and environmental management are present at the company. Lean management has been implemented since 2003. Initially, the company trained an internal team using a contracted consultancy. Then, in 2014 they decided to contract specialists from the market, with great experience in lean philosophy, in order to improve its use within the company. The firm uses lean in many processes and considers lean philosophy one of the pillars of the company.

Environmental management is also consolidated; the company has been developing activities in this direction since 1992, when they created the "support group for the environment". In 2003 they completed the ISO 14001 implementation process.

However, we observed that lean and green are treated in a separate or parallel way within the company. There are no lean and green departments or areas, no personnel tasked with duties to treat this subject together, nor are there teams/projects developing lean and green complementarities. When lean and green do overlap, it is not the result of an explicit strategy aimed to develop synergies between lean and green.

\begin{abstract}
"We use Lean Management in the company for many years and we have a Sustainability department to deal with many issues regarding environmental management, but we don't have a lean and green department or area. They are treated in a separately way within the company, but I believe that we have some practices that attend both." [I4]

"I am not directly involved with lean; I am not sure if there is direct connection with the environmental issues." [I1]

"In fact, we have many sustainable or environmental practices in the company, but related directly with lean we have the ones regarding waste reduction." [I3]
\end{abstract}

However, despite the lack of strategic intent, we observed that several lean and green synergic practices had nonetheless developed in the company and their results were perceived as valuable by managers.

\title{
4.1 Synergic practices findings \\ 4.1.1 Suppliers
}

A few years ago the company realized that they could better outsource the injection moulding of plastic parts. However, they decided to use an innovative approach to outsourcing. They called it "internal outsourcing". Outsourcing in this case meant opening a space "in house", inside the factory, for suppliers on a long-term contract to produce the parts contracted, with the focal company providing energy, water, and a space to install the suppliers' equipment in operation. The supplier's manager had a desk in the same building as the company's management and was supported by the company's administrative team. We refer to this practice as "hybrid sourcing". We found that hybrid sourcing resulted in a remarkable variety of lean and green synergies (see Table 3 ).

Table 3: Finding/Practice: Hybrid sourcing (plastic parts)

\begin{tabular}{|c|c|c|c|c|l|}
\hline Level & Category & $\begin{array}{l}\text { Helps } \\
\text { LM? }\end{array}$ & $\begin{array}{l}\text { Helps } \\
\text { EM? }\end{array}$ & Synergy? & Synergic results \\
\hline TI & S1-S7 & Yes & Yes & Yes & $\begin{array}{l}\text { Reducing of waste, reducing of transportation (costs and } \\
\text { emissions), reduction of costs for focal company and } \\
\text { O4 }\end{array}$ \\
O11 & & & $\begin{array}{l}\text { supplier, less waiting (people and machine), less packaging, } \\
\text { reducing of risk, better operational control, better auditing } \\
\text { process, reduction of lead-time and total time, information } \\
\text { Sharing and collaboration with suppliers. }\end{array}$ \\
\hline
\end{tabular}


"It is an 'internal outsourcing', and an excellent example of JIT and application of lean together following the same rules." [I1]

"Undoubtedly, the network collaboration programs are very important and are one of the KPI to make the lean and green management to work. I consider that the collaboration and training programs help to achieve synergy as well, as the result is better for both areas in a mixed and joined way." [I2]

“ 'internal outsourcing' has worked very well, with lower costs and wastes for both sides (for example costs with auditing, packaging, transportation, risks, time, among many others)." [I1]

We can connect this finding with all of lean and green practices from theory related to suppliers. About S1 (related to network, collaboration, and training), we could perceive they have more than one program of evaluation and training for suppliers, trying to achieve longterm relationships with them. An environment of collaboration and good communication with suppliers is easily recognizable in the company. There is an area at the company responsible for suppliers, named Supplies Area. This area has as one of their responsibilities the coordination of the relationship with all the suppliers.

This finding is also connected with S2 "Supplier evaluation/certification/auditing (environmental requirements)", S3 "Use of less/green packages (from suppliers)", S4 "Geographic concentration", S5 "Environmental risk sharing with suppliers", and S6 "Reducing number of suppliers".

Regarding the operations, we can connect this finding with three theoretical practices (O4, O11, and O14) as it can positively influence information sharing through the chain, waste reduction, less transportation and waiting (people and machines), reduction of lead time and total time of production, and more control in production and auditing.

Our next findings about supplier-oriented practices relate to synergies emerging from three practices in the company: the Award prize to suppliers, the ISO 9001/ISO 14001 certifications and EHS audits for suppliers, and the code of conduct for suppliers (see Table 4).

Table 4: Findings/Practices: Award prize to suppliers and Supplier's ISO certification ISO 9001 and ISO 14001

\begin{tabular}{|c|c|c|c|c|c|}
\hline Level & Category & $\begin{array}{l}\text { Helps } \\
\text { LM? }\end{array}$ & $\begin{array}{l}\text { Helps } \\
\text { EM? }\end{array}$ & Synergy? & Synergic results \\
\hline TI & $\begin{array}{c}\text { S1-S3 } \\
\text { S5 } \\
\text { O2 } \\
\text { O4 } \\
\text { O8 } \\
\text { O11 } \\
\text { O12 } \\
\text { O15 } \\
\text { O16 }\end{array}$ & Yes & Yes & Yes & $\begin{array}{l}\text { Information sharing and collaboration with suppliers in a } \\
\text { long-term relationship, continuous improvement, better } \\
\text { auditing process, reduction of waste, less packaging, better } \\
\text { operational control, reduction of costs for focal company and } \\
\text { suppliers, reducing of risk, reduction of defects. }\end{array}$ \\
\hline TI & $\begin{array}{c}\mathrm{S} 2 \\
\mathrm{~S} 5 \\
\mathrm{O} 4 \\
\mathrm{O} 13\end{array}$ & Yes & Yes & Yes & $\begin{array}{l}\text { Information sharing and collaboration with suppliers in a } \\
\text { long-term relationship, better auditing process, reducing of } \\
\text { risk, reduction of waste, reduction of defects. }\end{array}$ \\
\hline \multicolumn{6}{|c|}{$\begin{array}{ll}1 & \text { Quotations } \\
\end{array}$} \\
\hline
\end{tabular}

The company has a sustainability award aimed at suppliers. This award is based on economies in energy, water, waste, emissions, controlled substances, and social development. 
They invite all the suppliers to present a case supporting at least one of these issues. Then, a group of employees from the focal company audits the suppliers to better understand the case and to evaluate them. On Suppliers Day they give a prize to the top finishers, so the company clearly encourages sustainability practices from its suppliers. This relatively minor act of grateful recognition brings synergic lean and green results for the company.

Another supplier-oriented practice of the focal company is the requirement for their key suppliers to earn (at least) ISO 9001 and (preferably) 14001 certifications. In addition, the focal company audits all their suppliers according to EHS requirements. The frequency of auditing depends on how critical their products or services are to the focal company.

Finally, we observed that the company has a code of conduct for suppliers, which also resulted in lean and green synergies (see Table 5).

Table 5: Finding/Practice: Code of conduct for suppliers

\begin{tabular}{|c|c|c|c|c|l|}
\hline Level & Category & $\begin{array}{l}\text { Helps } \\
\text { LM? }\end{array}$ & $\begin{array}{l}\text { Helps } \\
\text { EM? }\end{array}$ & Synergy? & Synergic results \\
\hline TI & S1 & Yes & Yes & Yes & Information sharing and collaboration with suppliers in a \\
& S2 & & & & $\begin{array}{l}\text { long-term relationship, continuous improvement, better } \\
\text { auditing process, reduction of waste, emissions, hazardous } \\
\text { and pollution, reduction of risks and costs for focal company } \\
\text { Ond suppliers. }\end{array}$ \\
& O2 & & & \\
O11 & & & \\
O12 & & & \\
O15 & & & \\
O16 & & & \\
\hline
\end{tabular}

To become a supplier, contractors have to sign and fulfil this code of conduct. This code has concerns such as anti-corruption, freedom from slave labour, no child labour, environmental protection and biodiversity, protection of indigenous communities, among others. This practice has a shared responsibility between sustainability/green and supplies areas. The sustainability area is responsible for the identification and evaluation of the environmental risks and the supplies area is responsible for guaranteeing that the signed code is completely fulfilled, reducing or eliminating the co-shared risk.

\subsubsection{Operations}

An important finding was the observance of lean and green synergies resulting from employees' capacitation (see Table 6).

Table 6: Finding/Practice: Employees' capacitation

\begin{tabular}{|c|c|c|c|c|c|}
\hline Level & Category & $\begin{array}{l}\text { Helps } \\
\text { LM? }\end{array}$ & $\begin{array}{l}\text { Helps } \\
\text { EM? }\end{array}$ & Synergy? & Synergic results \\
\hline TI & $\begin{array}{l}\mathrm{O} 1 \\
\mathrm{O} 2 \\
\mathrm{O} 4 \\
\mathrm{O} 8 \\
\mathrm{O} 11 \\
\mathrm{O} 12 \\
\mathrm{O} 15 \\
\mathrm{O} 16\end{array}$ & Yes & Yes & Yes & $\begin{array}{l}\text { More employees involvement and empowerment, continuous } \\
\text { improvement, more control and evaluation (auditing), better } \\
\text { auditing process, less overproduction, fewer defects, } \\
\text { reduction of inappropriate processing, less waiting (people } \\
\text { and machine), less packaging (from suppliers and for } \\
\text { costumers), reduction of waste, reduction of pollution and } \\
\text { hazardous, reduction of costs, reduction of risk, better } \\
\text { operational control, information sharing and collaboration }\end{array}$ \\
\hline
\end{tabular}




\begin{tabular}{|l|c|c|}
\hline $\begin{array}{l}\mathrm{C} 2 \\
\mathrm{C} 4\end{array}$ & $\mid$ \\
\hline \multicolumn{1}{|c|}{ Quotations } \\
\hline "Since 2010 we use an array of Design for Environment (DfE). Through it we consider the various stages of the \\
life cycle and environmental impacts (water, energy, waste emissions and controlled substances). So we try to \\
improve the results with each release. It means: trying to reduce the energy consumption of water per cycle, \\
improve disassembly, use substances that can easily be separated and without legal restrictions, reducing the \\
intensity of use of natural resources, etc." [I1] \\
"We also have 100\% reverse logistics of our exchanged products for defect (quality) or problems with logistics \\
(delivery)." [I4] \\
"This leftover cardboard crushed, in the form of plots, is used to fill the empty space thus protecting the parts." \\
[II]
\end{tabular}

Reverse logistics is one of the green operational supply chain practices with more potential for synergies. They have $100 \%$ reverse logistics of their exchanged products for defect (quality) or problems with logistics (delivery). The company has also started a pilot program of exchanging old refrigerators for new refrigerators in some regions of Brazil. The old refrigerator should go to a business partner responsible to disassemble and sell or give the correct destination for the parts.

The other finding of synergy developed from green operational practices is also related with solid waste and is an example of 3Rs (reduce, reuse, recycle) program. The service area is responsible for sending spare parts to customers (technical assistance throughout Brazil). Instead of buying packaging fillers to protect the parts inside the boxes, the company acquired a machine that grinds pieces of cardboard (packaging leftovers).

\subsubsection{Customers}

Interestingly, both abovementioned synergic green operational practices required collaboration with customers to succeed. In terms of more specifically customer-focused practices, we found out that the lean and green practice "customer communication" produces synergies (see Table 9).

Table 9: Finding/Practice: Costumer communication programs

\begin{tabular}{|c|c|c|c|c|c|}
\hline Level & Category & $\begin{array}{l}\text { Helps } \\
\text { LM? }\end{array}$ & $\begin{array}{l}\text { Helps } \\
\text { EM? }\end{array}$ & Synergy? & Synergic results \\
\hline TI & C1 & Yes & Yes & Yes & $\begin{array}{l}\text { Better communication and sharing information with clients, } \\
\text { less defects, less inappropriate processing and reduction of } \\
\text { waste. }\end{array}$ \\
\hline \multicolumn{6}{|c|}{ Quotations } \\
\hline $\begin{array}{l}\text { "We monitor 100\% of products reclaims through Guaranty Programs, for all products. " [I4] } \\
\text { "We have surveys and events organized by the Marketing department that bring our customers to evaluate our } \\
\text { products, giving opinion and explaining their perception about the product usability. It helps us to produce } \\
\text { better products and attend their desires. It also helps lean and green, because (it) can reduce many types of } \\
\text { wastes." [I4] }\end{array}$
\end{tabular}

The marketing department uses tools such as a direct line with customers, satisfaction/opinion surveys, and laboratory testing in order to better understand the customers' needs and wants.

In summary, we found operational, supplier oriented, and customer oriented practices leading to synergies between lean and green, even when the company does not have a department or strategy for managing both together. However, perhaps as a consequence of 
this lack of strategic vision, we also found out that some of the practices identified in the literature as potentially leading to synergies did not add value to both green and lean performance. Moreover, three potentially synergic practices resulted in trade-offs or divergences between green and lean performance.

\subsection{Trade-offs}

Just-in-time (JIT) philosophy and its delivery is one of the practices leading to tradeoffs. JIT is strongly embedded in the company's business model and its top management has developed a series of actions to guarantee JIT delivery from their suppliers.

"JIT is a quality tool very important for us. We have and use JIT for many years; almost since we have got our first ISO 9001 certification; and we apply JIT in many suppliers.” [I1]

However, the synergy between lean and green and JIT is still not abundantly clear for the company. The lean manager does not consider this practice with green potential, since JIT needs as many deliveries as necessary to reduce inventory needs. This requirement is detrimental to green performance because it drastically increases $\mathrm{CO}_{2}$ emissions. Even taking into account the reduction in inventory and resulting economy in land use, he believes JIT is a trade-off and not a fully synergic practice.

"JIT, in my opinion, is a practice much more lean than green, even if I can, in some situations, recognize some benefits from environment, but not in all situations.'”[I3]

Another trade-off arises when lean and green practices increase production costs and are therefore resisted by customers. In 2011, using DfE (Design for Environment) methodology, the Product Development department developed a refrigerator using a new compressor with variable velocity, which saved up to $33 \%$ of energy consumption in use when compared to other refrigerators with normal compressors. The product was a marketing success - it gained some marketing prizes - but it was not a sales success. The problem was that the majority of Brazilian customers were not willing to pay more for this greener product, even with the prospect of future energy savings. The product was not discontinued, but production was reduced to meet the limited demand.

Finally, we have the Value Stream Map (VSM) and Sustainable Value Stream Map (SVMS) practices. The VSM is highly used and well-developed within the company. It is a tool very useful for everybody that works with lean. On the other hand, the SVSM was not found in the company; when we asked why, the answer was that they do not know how this tool could bring more value to lean as they already use VSM. Therefore, the successful use of VSM acted as a disincentive to implement SVSM despite the potential of the latter to improve green performance in addition to lean performance.

\section{Discussion}

As seen in Table 1, "waste reduction" practices were the most frequently cited practices involving lean and green. Approximately $76 \%$ of the papers mentioned waste reduction as a lean and green practice. We need to bear in mind that a lean perspective on waste reduction is different from a green perspective on waste reduction. As pointed out by Corbett and Klassen (2006), Dües et al. (2013) and Zokaei et al. (2013), waste reduction from a lean perspective focuses on the elimination of waste in all operational processes, internally and externally, that arise from overproduction, waiting, transportation, inappropriate processing, defects, and unnecessary inventory. On the other hand, waste reduction from a green perspective emphasizes the minimization of pollution, disassembly, redesign, waste 
segregation, and reuse and recycling. In turn, a lean and green perspective on waste reduction combines the value added for each of these distinct focuses. The results of our case study support the conceptualization of waste reduction practices as a key point of integration between lean and green practices leading to development of lean and green synergies.

An ongoing debate in lean and green literature considers the existence of trade-offs, which may arise between environmental objectives (waste reduction, carbon emission, energy consumption), and Supply Chain Management strategies (production, transportation, warehousing) of lean practice (Fahimnia et al., 2015). The identification of trade-offs is one recurrent gap in conceptual studies about lean and green connections, as trade-offs are strongly related to specific empirical contexts (Florida, 1996; Rothenberg et al., 2001; King and Lenox, 2001; Fahimnia et al., 2015).

From a general conceptual perspective, some works (i.e. Florida, 1996; Govindan et al., 2015; Dües et al., 2013) argue that the use of JIT practices may contribute to the reduction of inventory waste, but it may also increase energy consumption and $\mathrm{CO}_{2}$ emissions due to more frequent delivery of inputs. Fahimnia et al. (2015) used a tactical supply chain planning model to investigate trade-offs between cost and environmental degradation, including carbon emissions, energy consumption and waste generation. The proposed model also incorporated other aspects of real world supply chains such as multiple transport lot sizing and flexible holding capacity of warehouses. They obtained two major results: (1) not all lean interventions at the tactical supply chain planning level result in green benefits, and (2) a flexible supply chain with a well-managed inventory is the greenest and most efficient alternative when compared to strictly JIT lean and centralized situations. On the other hand, Jabbour et al. (2013b) did not find empirical evidence supporting the existence of a negative and inversely proportional correlation between JIT and environmental management benefits.

The results of our case study provide evidence of trade-offs between lean and green at the focal company operations. We found such trade-offs associated with JIT delivery, JIT philosophy, inventory reduction, and Value Stream Maps/Sustainable Value Stream Maps. Our results complement the arguments of Fahimnia et al. (2015). When a company's adherence to lean practice and philosophy is too strict and dominates the operational strategy and vision of the company, then synergies between lean and green are less likely to develop and trade-offs are more likely to arise. For instance, the company does not use Sustainable Value Stream Maps because the company cannot see what SVSM could add to Value Stream Maps; they resisted SVMS implementation invoking overlaps and switching costs.

However, despite the dominance of lean perspectives in operations, and notwithstanding the lack of organizational incentives and spaces to share knowledge and to develop joint-learning between the lean and green areas; our case study still found numerous practices leading to well-developed synergies between lean and green. The majority of these practices were related to suppliers: i) the hybrid sourcing practice used with plastic parts, ii) the award prize to suppliers, iii) the ISO 9001 and ISO 14001 certifications for suppliers, and iv) the code of conduct. These four practices related to suppliers are synergic because they bring better results for the company in both ways. Related to lean because they can eliminate unnecessary inventory, transportation, lead-time, waiting time. In addition, green offers benefits because they can reduce packaging, emissions and pollution. Besides, these four practices also add value to the company by helping to consolidate more long-term relationships, to reduce risks and improve communication, auditing, and control processes. Therefore, they can be considered truly lean and green synergic practices. Our empirical findings support conceptual literature arguing that close collaboration with supply chain partners, especially suppliers, is a synergic lean and green practice (Dües et al., 2013). This is an important finding, because as pointed out by Simpson and Power (2005), suppliers can have a direct impact on a customer's critical dimensions of cost, quality, technology, delivery, 
flexibility, and profits.

Simpson and Power (2005) also affirm that developing and maintaining a good supply relationship can be achieved through either collaboration or compliance. Trust provides a basis for achieving collaboration, while power serves as a mechanism for achieving compliance. Therefore, in a supply chain perspective we can recognize three important factors influencing lean and green synergy: empowered lean and green areas, trust, and long-term relationships.

According to all interviewed staff, our own observations, and secondary data analysis, the company is equally concerned about the lean aspects and the green aspects of their suppliers' performance. Therefore, both lean and green managers are similarly empowered by the focal firm to seek suppliers' compliance with their requirements. Green managers are empowered by the requirement of ISO14001, the importance given to environmental performance in the awards for suppliers (lead by the environmental manager), and the strict enforcement of compliance with the code of conduct (developed by the green area and enforced by supply area). The high frequency of interaction between environmental managers and suppliers resulting from these practices also leads to the development of trust and longterm relationships where suppliers and managers jointly learn how to address problems and find solutions. The similar importance attached by the company to lean and green in their supply chain, and the balanced interaction between suppliers and the focal firm's operation manager, environmental manager, supply manager and marketing manager, may go a long way to explain why lean and green synergies develop in practices related to suppliers and customers.

In addition to power and trust, risk-sharing propensity emerges from our case study as an important driver for lean and green synergies. We define risk-sharing propensity as the tendency to reduce costs associated with risk prevention through the involvement of partners. Corbett and Klassen (2006) affirm that environmental incidents can cause financial harm through disruptions or product liability in supply chains. These four practices: i) the hybrid sourcing practice with plastic parts, ii) the award prize to suppliers, iii) the ISO 9001 and ISO 14001 certifications for suppliers, and iv) the code of conduct, seek to somehow protect the focal company against any legal problems or liabilities that may be associated indirectly to its activities, through its suppliers. In some way, the practices are a covenant of trusting and risk sharing between the focal company and their suppliers.

\footnotetext{
"Reducing risks is a great concern nowadays. As the market is each day more competitive, we cannot commit mistakes. So, one of the ways to reduce risks is involving suppliers and sharing with them information and responsibilities. This can be important for lean and green as well, if our suppliers understand that they have to reduce all types of wastes, pollution, use of resources and avoid liabilities when they are producing parts of our products." [ID]
}

Regarding operations, where lean aspects are clearly the main concern and environmental managers are less empowered, the main practices leading to development of lean and green synergies are: i) employees' capacitation (involvement and empowerment), ii) operations and quality practices/philosophies/programs, and iii) green technology.

The focal company has many different types of employee training related to lean, green, and other subjects such as health and safety, security, quality, and effective communication. This practice can be considered synergic because it brings better results not only for lean and green systems, but for the company in general; having more employees involved and empowered, reducing risks, and having more control and evaluation (auditing) are beneficial skills both for individual employees and for the focal company. Specifically for lean and green, we observed synergic results such as less overproduction, fewer defects, 
reduction of inappropriate processing, less packaging (from suppliers and for customers), reduction of waste, pollution, and use of hazardous materials.

Risk sharing again appears to be a key driver behind synergies arising from employee involvement with different levels of operations. According to Sobral et al. (2013), lean practices are related with green practices through the involvement of employees with continuous improvement, the reduction of inventories, and collaboration with suppliers. Employee involvement and empowerment expands awareness of potential environmental risks, facilitates the emergence of "bottom up" solutions, and extends product liability to all employees and the entire supply chain. However, as pointed out by Boiral (2005), assessing the influence of human factors in pollution reduction is very difficult, particularly at the operations level. So, even if training and empowerment are important issues, how to measure the influence of these factors in the development of synergies is still difficult.

About green technology we found out two 3R risk-sharing situations showing lean and green synergy: the exchange of refrigerators' programme and the replacement of packaging fillers with grinded cardboard leftovers. Both practices share risks with customers through their involvement in waste reduction activities. Both practices require the collaboration of customers to be successful, especially the first one which is aligned with Brazilian waste management legislation, "Politica Nacional de Residuos Solidos n.12305/2010 (PNRS)" (Brazilian National Policy of Solid Waste) that came into force at the end of 2010 and makes companies responsible for the waste generated when products reach the end of their life cycle.

We also found out evidences of synergy in other corporate practices involving customers. In all cases, communication with customers was the focal point leading to synergies. The case of the new compressor with variable velocity saving up to $33 \%$ of energy consumption is one situation that shows the importance of capturing the consumer's desire before manufacturing the product. Our findings are aligned with Carvalho et al.'s (2011) lean and green conceptual model. In this model, the customer relationship is one of the most important linkages between lean, agile, resilient, and green practices and supply chain management attributes.

Overall we identified more synergies than divergences or trade-offs when we looked for lean and green practices in our case study. The exception was the operational level where some lean practices presented trade-offs and several green practices - apart from waste management - are yet to be fully implemented in the company, as they use them just in some products and some processes. Therefore, synergies were weak or there was not enough evidence to evaluate its impact.

It was not our original intent to explore the drivers that make synergy happen or the obstacles to synergy development. However, we perceived in a first round of analysis that waste reduction, trust, long-term relationships, communication, empowerment, risk-sharing, training and low power differentials between lean and green functions were all important bases for synergy. On the other hand, we found costs, strict and dominant lean philosophy, and non-supportive management team as possible obstacles for lean and green synergy. We then went back to our data and the literature looking for transversal themes connecting drivers and obstacles identified. This re-evaluation allowed us to outline an emerging framework to explain the occurrence or absence of synergies in supply chains. Such framework comprises five elements: quality of knowledge, relatedness of knowledge, power of functional areas, trust, and risk-sharing propensity.

As the literature on synergies in mergers and acquisitions has shown, the extent to which the combination of two distinct sets of knowledge resources delivers synergies depends upon the quality of the knowledge and the extent to which knowledge resources complement and relate to each other (Gupta and Roos, 2001). The quality of both lean and green knowledge in the case study company was good. Training and empowerment of employees 
and regular use of consultants helped to enhance the firms' knowledge.

However, quality of knowledge is not the only prerequisite for synergies. Knowledge fields must also complement and relate to each other. Conceptually, as we discussed in the case of waste management, there is a strong complementarity and relatedness between lean and green knowledge resources. This implies potentially lower coordination and communication costs between lean and green units within a firm, enabling them to work together more easily (Karim and Kaul, 2015). However, the lean and green departments in our case had very limited interaction and there was no exchange of knowledge or development of joint projects. One of the reasons we found to explain this fact and some of the divergences between lean and green are that the company treats lean and green in a parallel way (Martinez et al., 2012), without a department or a supportive management team to address them in a joined way. Both formal and informal communications between the lean team and the green team are weak. Therefore, although the fields of knowledge are conceptually related, there is no physical or interactional relatedness between knowledge bearers. As a consequence, the intra-organizational recombination of knowledge is hampered. In fact, this situation was found before in some other research (Sobral et al., 2013; Pampanelli et al., 2014; Galeazzo et al., 2014). Pampanelli et al. (2014) also confirmed that one of the most important points for a Lean \& Green Model is a supportive management team.

Quality of knowledge and relatedness of knowledge bearers help us to understand when there is potential for lean and green synergies. In turn, three other constructs helped us to understand when the potential for synergies was realised and when it was not: trust, power differentials and risk sharing propensity.

At the supply chain level, synergies in our case study are higher when: a) trust between actors is high (long-term relationship), b) both lean and green managers are equally influential on suppliers, and c) risk-sharing propensity is high (extended producer responsibility). Regarding the latter, several of the synergic practices identified - from codes of conduct to the exchange of old for new refrigerators - can be seen as risk-sharing practices partially triggered by Brazil's newly-enacted waste management regulations. These practices are intended to spread the increased costs of environmental management among customers and suppliers.

At the operational level, top management perceptions of high costs of green practices and power differentials between lean and green explain the existence of trade-offs where green is subordinated to lean. In our case study, since JIT is one of the pillars of the company's operations model, the lean department is more powerful than the green department in terms of operative decisions. Our findings resonate with Simpson and Samson's (2010) observation that the organization may choose to develop a set of operational practices that support its environmental performance and later be unable to resolve internal conflicts between environmental performance and other economically relevant functions of the organization.

However, synergies still occurred spontaneously. This happened when intraorganizational knowledge recombination was catalysed by risk-sharing practices such as suppliers dealing with both lean and green demands or by employees empowered by training in lean and green issues. In all the cases, the lack of interaction between lean and green areas was overcome because a third party triggered synergies, creating channels for knowledge transfer and development of complementarities between business functions that worked otherwise in organizational silos. The more trusted the catalyst party, the stronger the synergy. Hybrid sourcing, which involved highly trusted long-term suppliers manufacturing their products within the focal firms, was one of the practices unleashing wider and stronger synergies.

The following graph (Figure 1) represents the relationships identified in the case 
study.

Figure 1: Relationships identified in the case study (framework)

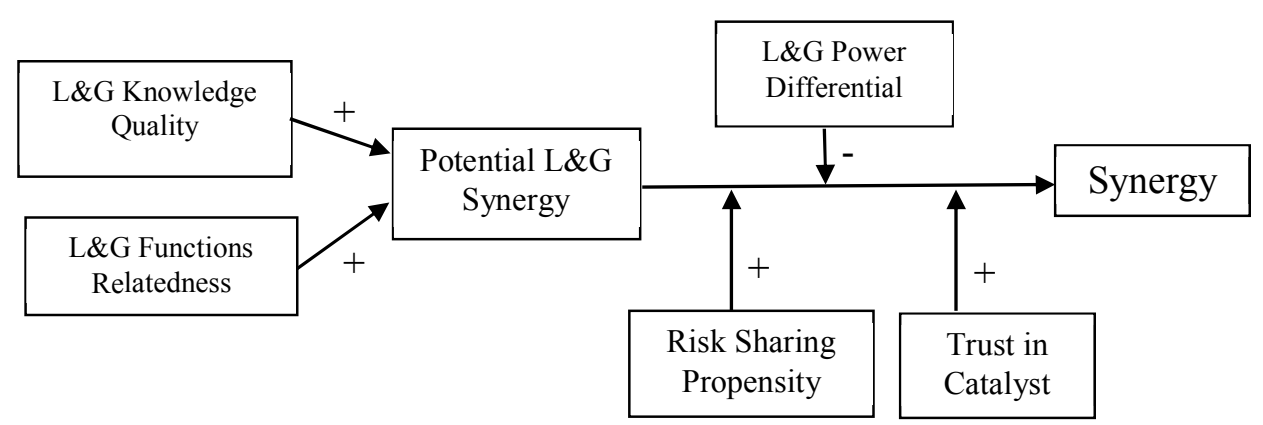

\section{Conclusions}

From a general point of view, we can see in Figure 2 that there are only five practices from the 31 integrated practices from literature review (Table 1) that were not considered synergic for lean and green in this case study. Four items are non-synergic and present some trade-offs: JIT delivery (S7), JIT philosophy (O19), Inventory reduction (O3), and VSM/SVSM (O18). All four non-synergic practices are considered important for lean, but the green potential was not identified. On the other hand, we also found one practice, Use of green technology (O17), partially implemented in the company with more green than lean potential. Again, in this case we could not consider the practice as totally synergic, since the lean benefits were weak.

Figure 2: Synergic relation to lean and green

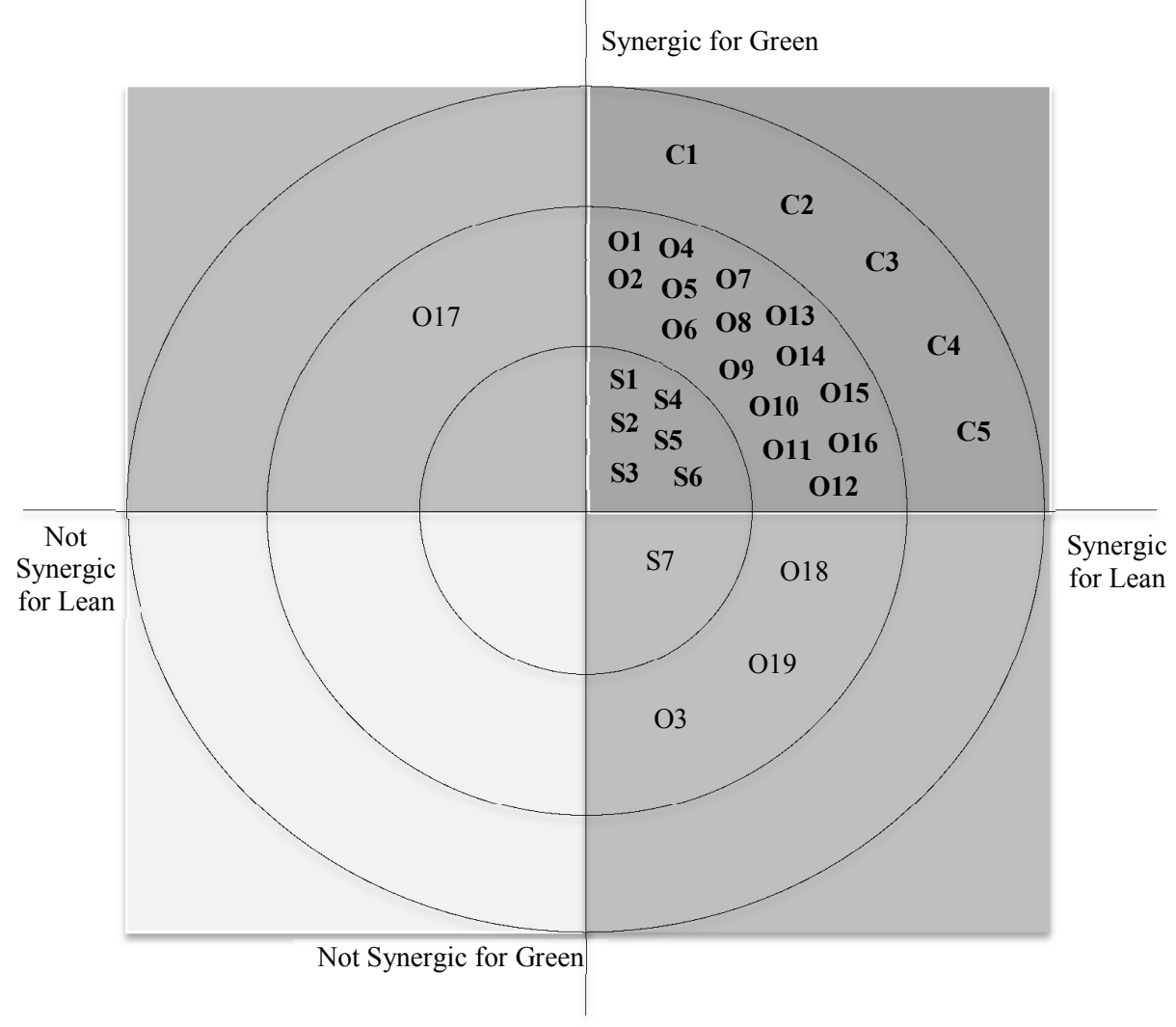


Another point we can highlight is that much of the synergic results have some relation with waste reduction, even if lean and green have different points of view about what waste reduction means. We can argue that for a lean and green model, waste reduction would be a focal point, and other practices could come in order to help or improve this practice or result.

Although the study was developed in a Brazilian company, we believe that its implications go beyond a better understanding of synergies within a particular company context. Our paper makes both an empirical and theoretical contribution transcending company-specific and country-specific findings.

Empirically, it is the first time that all the practices identified in the literature are systematically explored in a case study. As such, our study bridges the gap between lean and green literature, where the process of synergies' formation and implementation has been under examined both empirically and conceptually (Piercy and Rich, 2015). Our results show that lean and green synergies can emerge spontaneously (rather than being strategized) even when implementation of green and lean practices is compartmentalised in different areas without a department or a supportive management team to treat them in a joined way. An interesting implication for management practice is that the strongest synergies emerge from practices related to suppliers and customers. As both "lean" and "green" managers interact with them, supply chain actors provide channels for knowledge transfer and development of complementarities between business functions that work otherwise in organizational silos. Therefore, increasing the engagement of customers and suppliers with lean and green teams can provide an alternative synergy-enabler mechanism for companies that are unwilling, or unable, to change the balance of power between internal functions and to actively intervene to make lean and green teams work together. The results also bring attention to a practice not previously identified in our literature review: hybrid sourcing. Hybrid sourcing refers to a mode of supply where the production line of long-term suppliers is hosted inside the focal firm's factory and uses the focal firm's physical and administrative resources. We observed significant synergies arising from hybrid sourcing.

This insight suggests that companies interested in exploiting synergies should enhance customers' and suppliers' integration with business practices and pay more attention to hybrid sourcing as a pathway to enable lean and green. However, further studies are needed to explore more carefully the factors influencing the success of hybrid sourcing and its potential disadvantages.

Theoretically, we developed a model of determinants on lean and green synergies based on constructs emerging from our data and elements from merger and acquisitions literature in synergies. This model differentiates between two sets of factors: those that influence the potential to develop lean and green synergies (quality and relatedness of knowledge) and those that influence the realization of synergy potential (power differential of knowledge bearers, trust and risk-sharing propensity). The potential for lean and green synergy is fully realized when there is a high level of trust and risk-sharing propensity and a low level of power differentials between lean and green functions. We further propose that: a) environmental regulations for extended producer responsibility may increase risk-sharing propensity, b) strong communications along the supply chain build trust, c) power differentials may be reified when the principles supported by one particular business function of the company (in this case the lean philosophy underlying the production function) become the dominant philosophy for the company as a whole. We suggest that our theoretical contributions can be applied more generally to explain the occurrence of synergies between any two distinct types of knowledge or business practices, and not necessarily only between lean and green. Further research could test the model, for instance, to analyse synergies between social and environmental practices. 
We can point out several limitations of this research. The first one is that we did not have access to the focal company's customers and suppliers. This made our analysis of drivers skewed towards the perspective of the focal company managers and the way they framed their interactions. Secondly, our assessment of synergies was, in the majority of cases, qualitative. Another limitation is that it is an exploratory case study and the results cannot be generalised without wider testing. Our results are closely related to the situation of this company and this particular time span. However, given that lean and green synergic practices have been very sparsely explored and discussed by supply management literature, we consider that our empirical findings and conceptual propositions open avenues of inquiry for further research to develop, to pursue different contexts or challenges, and to contribute to emerging research agendas on lean and green synergic practices.

As suggestions for future studies we highlight four possibilities: i) better exploring of what makes synergy happen; ii) studying in-depth the trade-offs or the "non-synergic" practices, iii) investigating in more detail the antecedents or possible mediators of factors influencing synergies (i.e., industry differences, environmental factors such as munificence and uncertainty) coupled with the influence of institutional pressures, and iv) developing a survey with suppliers and customers in order to identify if, from their point of view, they recognize synergy in these practices as well, and how different is the scenario throughout the entire supply chain.

\section{Acknowledgement}

The authors would like to thank CNPq (National Council of Technological and Scientific Development) for supporting this research.

\section{References}

Anand, G. and Kodali, R. (2008), "A conceptual framework for lean supply chain and its implementation", International Journal of Value Chain Management, Vol. 2, pp.313-357.

Anand, G. and Kodali, R. (2010), "Development of a framework for implementation of lean manufacturing systems", International Journal of Management Practice, Vol. 4 No. 1, pp.95116.

Arantes, A.F., Jabbour, A.B.L.S. and Jabbour, C.J.C. (2014), "Adoption of Green Supply Chain Management practices: mechanisms of induction and the role of focal companies", Production Journal, Vol. 24 No. 4, pp. 725-734.

Azevedo, S.G., Carvalho, H., Duarte, S. and Cruz-Machado, V. (2011), "The influence of green practices on supply chain performance: a case study approach", Transportation Research Part E, Vol. 47, pp. 850-871.

Azevedo, S.G., Carvalho, H., Duarte, S. and Cruz-Machado, V. (2012), "Influence of green and lean upstream supply chain management practices on business sustainability", IEEE Transactions on Engineering Management, Vol. 59 No. 4, pp. 753-765.

Boiral, O. (2005), "The impact of operator involvement in pollution reduction: case studies in Canadian chemical companies", Business Strategy and Environment, Vol. 14, pp. 339-360.

Calife, N.F.S., Nogueira, E. and Alves Filho, A.G. (2010), "White goods companies and their competitive and operations Strategies", Produção Online, Vol. 10 No. 2, pp. 274-396.

Capaldo, A. and Giannocaro, I. (2015), "How does trust affects affect performance in the supply chain? The moderating role of interdependence", International Journal of Production Economics, Vol. 166, pp. 36-49. 
Carnabucci, G. and Operti, E. (2013), "Where do firms' recombinant capabilities come from? Intraorganizational networks, knowledge, and firms' ability to innovate through technological recombination”, Strategic Management Journal, Vol. 34 No. 13, pp. 1591-1613.

Carvalho, H., Azevedo, S.G. and Cruz-Machado, V. (2010), "Supply chain performance management: lean and green paradigms", International Journal Business Performance and Supply Chain Modelling, Vol. 2 No. 3/4, pp. 304-333.

Carvalho, H., Duarte, S. and Cruz Machado, V. (2011), "Lean, agile, resilient and green: divergencies and synergies", International Journal of Lean Six Sigma, Vol. 2 No. 2, pp. 151179.

Corbett, C.J. and Klassen, R.D. (2006), "Extending the Horizons: Environmental Excellence as Key to Improving Operations", Manufacturing \& Services Operations Management, Vol. 8 No. 1, pp. 5-22.

Dabhilkar, M., Bengtsson, L. and Lakemond, N. (2016), "Sustainable Supply Chain Management as purchasing capability: a power and dependence perspective", International Journal of Operations and Production Management, Vol. 36 No. 1, pp. 2-22.

Duarte, S. and Cruz-Machado, V. (2015), "Investigating lean and green supply chain linkages through a balanced scorecard framework", International Journal of Management Science and Engineering Management, Vol. 10 No. 1, pp. 20-29.

Dües, C.M., Tan, K.H. and Lim, M. (2013), "Green as the new lean: how to use lean practices as a catalyst to greening your supply chain”, Journal of Cleaner Production, Vol. 40, pp. 93100 .

Espadinha-Cruz, P. Grilo, A., Puga-Leal, R. and Cruz-Machado, V. (2011), “A model for evaluating lean, agile, resilient and green practices interoperability in supply chains", Proceedings of 2011 IEEE International Conference on Industrial Engineering and Engineering Management, December 6-9, 2011, Singapore, pp. 1209-1213.

Fahimnia, B., Jabbarzadeh, A., Sarkis, J. (2015), "A tradeoff model for green supply chain planning: a leanness-versus-greenness analysis”, Omega, Vol. 54, pp. 173-190.

Florida, R. (1996), "Lean and Green: The move to environmentally conscious manufacturing", California Management Review, Vol. 39 No.1, pp. 80-105.

Forrester, P.L., Shimizu, U.K., Soriano-Meier, H., Garza-Reyes, J.A. and Cruz Basso, L.F. (2010), "Lean Production, market share and value creation in the agricultural machinery sector in Brazil", Journal of Manufacturing and Technology Management, Vol. 21 No.7, pp. 853-871.

Galeazzo, A., Furlan, A., Vinelli, A. (2014), "Lean and green in action: interdependencies and performance of pollution prevention projects", Journal of Cleaner Production, Vol. 85, pp. 191-200.

Garza-Reyes, J.A. (2015), "Lean and green - a systematic review of the state of the art literature”, Journal of Cleaner Production, Vol. 102, pp. 18-29.

Giamakis, M, and Croom, S.R. (2004), "Toward the development of a supply chain management paradigm: a conceptual framework", Journal of Supply Chain Management, Vol. 40 No. 1, pp. 27-37.

González-Benito, J. (2008), “The effect of manufacturing pro-activity on environmental management: an exploratory analysis", International Journal of Production Research, Vol. 46 No. 24, pp. 7017-7038. 
Goold, M. and Campbell, A. (1998), "Desperately seeking energy", Harvard Business Review, Sept-Oct, pp. 132-142.

Govindan, K., Azevedo, S. Carvalho, H. Cruz-Machado, V. (2015), "Lean, green and resilient practices influence on supply chain performance: interpretive structural modelling approach", International Journal of Environmental Science Technology, Vol. 12, pp. 15-34.

Gupta, O. and Roos, G. (2001). "Mergers and acquisitions through an intellectual capital perspective”, Journal of Intellectual Capital, Vol. 2 No. 3, pp. 297-309.

Gurumurthy, A. and Kodali, R. (2009) "Application of benchmarking for assessing the lean manufacturing implementation", Benchmarking: An International Journal, Vol. 16 No. 2, pp. 274-308.

Hajmohammad, S., Vachon, S., Klassen, R.D. and Gavronski, I. (2013), "Lean management and supply management: their role in green practices and performance", Journal of Cleaner Production, Vol. 39, pp. 312-320.

Handfield, R and Bechtal, C. (2004), “Trust, Power, Dependence and Economics: can SCM research borrow paradigms?", International Journal of Integrated Supply Chain Management, Vol. 1 No. 1, pp. 3-32.

Hardy, C, Philips, N. and Lawrence, T. (1998), "Distinguishing trust and power in interorganizational relations: forms and façades of trust", in Lane, C. and Bachman, C. (Eds.) Trust in and within organizations, Oxford: Oxford University Press, pp. 64-87.

Hoejmose, S., Brammer, S., and Millington, A. (2012), ““'Green” supply chain management: the role of trust and top management in B2B and B2C markets", Industrial Marketing Management, Vol. 41 No. 4, pp. 609-620.

Jabbour, A.B.L.S., Arantes, A.F. and Jabbour, C.J.C. (2013a), "Green supply chain management: mapping the territory", International Journal of Environment and Sustainable Development, Vol. 12 No. 2, pp. 145-167.

Jabbour, A.B.L.S., Jabbour, C.J.C., Freitas, W.R.S. and Teixeira, A.A. (2013b), "Lean and green? Empirical evidence from the Brazilian automotive industry”, Gestão \& Produção, Vol. 20 No. 3, pp. 653-665.

Karim, S. and Kaul, A. (2015), "Structural recombination and innovation: Unlocking intraorganizational knowledge synergy through structural change", Organization Science, Vol. 26 No. 2, pp. 439-455.

King, A.A. and Lenox, M.J. (2001), "Lean and green? An empirical examination of the relationship between lean production and environmental performance", Production and Operations Management, Vol. 10, pp. 244-256.

Kogut, B. and Zander, U. (1992), "Knowledge of the Firm, Combinative Capabilities, and the Replication of Technology”, Organization Science, Vol. 3 No.3, pp. 383-397.

Larsson, R. and Finkelstein, S. (1999), "Integrating strategic, organizational and human resource perspectives on mergers and acquisitions: a case study of synergy realization", Organization Science, Vol. 10, pp. 1-26.

Lasker, R., Weiss, E. and Miller, R. (2001), "Partnership synergy: a practical framework for studying and strengthening collaborative advantage", The Milbank Quarterly, Vol. 79 No. 2, pp. 179-205. 
Lee, B-C., Kim, P-S., Hong, K-S. and Lee, I. (2010), "Evaluating antecedents and consequences of supply chain activities: an integrative perspective", International, Journal of Production Research, Vol. 48 No. 3, pp. 657-682.

Makri, M., Hitt, M.A. and Lane, P.J. (2010), "Complementary technologies, knowledge relatedness, and invention outcomes in high technology mergers and acquisitions", Strategic Management Journal, Vol. 31 No. 6, pp. 602-628.

Martinez, F., Vazquez-Brust, D.A., Peattie, K. and Zokaei, K. (2012), "Achieving greener growth: a business perspective for proactive commitment (Chapter 10)", in Vazquez-Brust, D.A. and Sarkis, J. (eds.) Green Growth: Managing the Transition to a Sustainable Economy, Greening of Industry Networks Studies 1, Springer.

Maxwell, J., Briscoe, F. Schenk, B. and Rothenberg, S. (1998), "Case study: Honda of America Manufacturing, Inc.: Can lean production practices increase environmental performance?”, Environmental Quality Management, Vol. 8 No.1, pp. 53-61.

Miller, G., Pawloski, J. and Standridge, C.R. (2010), "A case of lean, sustainable manufacturing", Journal of Industrial Engineering and Management, Vol. 3, pp. 11-32.

Pampanelli, A.B., Found, P. and Bernardes, A.M. (2014), "A Lean \& Green Model for a production cell”, Journal of Cleaner Production, Vol. 85, pp. 19-30.

Parveen, C.M., Kumar, A.R.P., Narasimha Rao, T.V.V.L. (2011), "Integration of lean and green supply chain - impact on manufacturing firms in improving environmental efficiencies", Proceedings of International Conference on Green Technology and Environmental Conservation (GTEC), Chennai, India, December 15-17, pp. 143-147.

Piercy, N. and Rich, N. (2015), "The relationship between lean operations and sustainable operations", International Journal of Operations \& Production Management, Vol. 35 No. 2, pp. 282-315.

Pojasek, R.B. (2008), “Quality toolbox: Framing your lean-to-green effort”, Environmental Quality Management, Vol. 18 No. 1, pp. 85-93.

Rothenberg, S., Pil, F.K. and Maxwell, J. (2001), "Lean, green, and the quest for superior environmental performance", Production and Operations Management, Vol. 10 No. 3, pp. 228-243.

Russo, M. and Fouts, P. (1997), "A resource-based perspective on corporate environmental performance and profitability", Academy of Management Journal, Vol. 40 No. 3, pp. 534539.

Shah, R. and Ward, P.T. (2003), "Lean manufacturing: context, practice bundles, and performance”, Journal of Operations Management, Vol. 21 No. 2, pp. 129-149.

Shah, R. and Ward, P.T. (2007), "Defining and developing measures of lean production", Journal of Operations Management, Vol. 25, pp. 785-805.

Simatupang, T., Wright, A.C. and Sridharan, R. (2004), “Applying the theory of constraints to supply chain collaboration”, Supply Chain Management: An International Journal, Vol. 9, pp. 57-70.

Simpson, D.F. and Power, D.J. (2005), "Use the supply relationship to develop lean and green suppliers”, Supply Chain Management: An International Journal, Vol. 10 No. 1, pp. 60-68.

Simpson, D. and Samson, D. (2010), "Environmental strategy and low waste operations: exploring complementarities", Business Strategy and the Environment, Vol. 19, pp. 104-118. 
Sobral, M.C.S., Jabbour, A.B.L.S. and Jabbour, C.J.C. (2013), "Green benefits from adopting Lean Manufacturing: A case study from the automotive sector", Environmental Quality Management, Vol. 22 No. 3, pp. 65-72.

Vais, A., Miron, V., Pedersen, M. and Folke, J. (2006), "Lean and green at a Romanian secondary tissue paper and board mill - Putting theory into practice", Resources, Conservation \& Recycling, Vol. 46, pp. 44-74.

Wiengarten, F., Fynes, B. and Onofrei, G. (2013), "Exploring synergetic effects between investments in environmental and quality/lean practices in supply chains", Supply Chain Management: An International Journal, Vol. 18 No. 2, pp. 148-160.

$\mathrm{Wu}, \mathrm{W}-\mathrm{Y}$., Chiag, C-Y., Wu, Y-J. and Tu, H-J. (2004), "The influencing factors of commitment and business integration on Supply Chain Management", Industrial Management and Data Systems, Vol. 104 No. 4, pp. 322-333.

Yin, R.K. (1994), Case study research: design and methods. Newbury Park, CA: Sage Publications.

Zhao, X., Huo, B., Flynn, B. and Yeung, J. (2008), "The impact of power relationship commitment on the integration between manufacturers and customers in a supply chain", Journal of Operations Management, Vol. 26 No. 3, 368-388.

Zokaei, K., Lovins, H., Wood, A. and Hines, P. (2013), Creating a Lean and Green Business System: Techniques for Improving Profits and Sustainability, CRC Press, Taylor \& Francis Group. 